\title{
Study of Oxidation Kinetics in Air of Zircaloy-4 by in Situ X-Ray Diffraction
}

\author{
Noureddine Selmi, Ali Sari \\ Nuclear Research Center of Birine, Birine, Algeria \\ Email: selm2002nor@yahoo.fr, sariali63@yahoo.fr
}

Received April 2, 2013; revised May 9, 2013; accepted May 20, 2013

Copyright (C) 2013 Noureddine Selmi, Ali Sari. This is an open access article distributed under the Creative Commons Attribution License, which permits unrestricted use, distribution, and reproduction in any medium, provided the original work is properly cited.

\begin{abstract}
The zircaloy-4 is an alloy of zirconium, which has a very weak thermal neutron absorption, satisfactory mechanical properties and good corrosion resistance at high temperature. For these reasons, zircaloy-4 is used as a material of cladding fuel rod of nuclear reactors. In this environment, it is submitted to different severe conditions of temperature and pressure. The objective of this work is to study the oxidation kinetics of zircaloy-4 in air by the X-ray diffraction technique. The experiments were realized in a "HTK1200" furnace installed as a sample holder in the diffractometer at different temperatures; $25^{\circ} \mathrm{C}, 350^{\circ} \mathrm{C}, 500^{\circ} \mathrm{C}, 830^{\circ} \mathrm{C}$ and $1000^{\circ} \mathrm{C}$. The results show that the monoclinic and the tetragonal phases are formed at $350^{\circ} \mathrm{C}$ temperature. The volume fraction of these phases increased with the temperature until $1000^{\circ} \mathrm{C}$ where the $\alpha$ phase disappears completely. For simulating the case of loss-of-coolant-accident (LOCA), we have done $\mathrm{x}$-ray diffraction of Zry-4 samples water quenched at $1050^{\circ} \mathrm{C}$ with different ageing times at this temperature. At 10 seconds and more, there is an important evolution of monoclinic and tetragonal zirconias, which leads to the degradation of zircaloy-4 properties.
\end{abstract}

Keywords: Zircaloy-4; High Temperature Oxidation; Zirconium Oxides; In Situ X-Ray Diffraction

\section{Introduction}

The fuel rod cladding represents the first barrier of the radioactive products confinement. The use of zirconium alloys for the cladding fuel rod of the pressurized water of the nuclear reactors (P.W.R.) is related to their very weak absorption of the thermal neutrons, good water corrosion resistance, good mechanical properties at high temperature [1], compatibility with the fuel and sufficient resistance to the irradiation effects (embrittlement, swelling ...) (Figure 1). This material is submitted to the extreme conditions of the use, and various phenomena which degrade their characteristics. Among these phenomena there is the oxidation by water.

Zircaloy-4 oxidation in air proceeds in a similar way to that described in the pressurized steam. In this work, we studied the oxidation of the zircaloy- 4 in air, and we have chosen various temperatures; $25^{\circ} \mathrm{C}, 350^{\circ} \mathrm{C}, 500^{\circ} \mathrm{C}, 830^{\circ} \mathrm{C}$ and $1000^{\circ} \mathrm{C}$.

\subsection{Allotropic Phases of the $\mathrm{Zr}$}

At atmospheric pressure, and temperature inferior to $866^{\circ} \mathrm{C}$, elemental $\mathrm{Zr}$ appears as the hcp $\alpha$-phase. At temperature between $866^{\circ} \mathrm{C}$ and $1850^{\circ} \mathrm{C}, \mathrm{Zr}$ appears as the bcc $\beta$-phase. At room temperature and at pressure of about $2 \mathrm{GPa}$ and more, the hep $\alpha$-phase is transformed to the hexagonal $\omega$-phase [2].

\subsection{Zr-O System}

The phase diagram of the binary system $\mathrm{Zr}-\mathrm{O}$ presented in Figure 2 [3] shows that a great quantity of oxygen can dissolve in interstitial position (until $30 \%$ at $500^{\circ} \mathrm{C}$ ) on one hand and on the other hand, there exists one stable zirconium oxide with atmospheric pressure, the $\mathrm{ZrO}_{2}$ zirconia.

At atmospheric pressure, and at a temperature that reaches $1170^{\circ} \mathrm{C}$, the crystalline structure of $\mathrm{ZrO}_{2}$ is monoclinic, between $1170^{\circ} \mathrm{C}$ and $2370^{\circ} \mathrm{C}$, the monoclinic structure becomes tetragonal structure, and cubic structure from $2370^{\circ} \mathrm{C}$ to $2706^{\circ} \mathrm{C}[4,5]$.

\subsection{Oxidation Mechanism}

The oxidation of zirconium and its alloys progresses by a diffusive stage of anionic type, i.e. the growth of the products of the oxidation of metal is carried out by transport of oxygen of the gas environment towards the interface metal/oxide (intern interface) according to the 


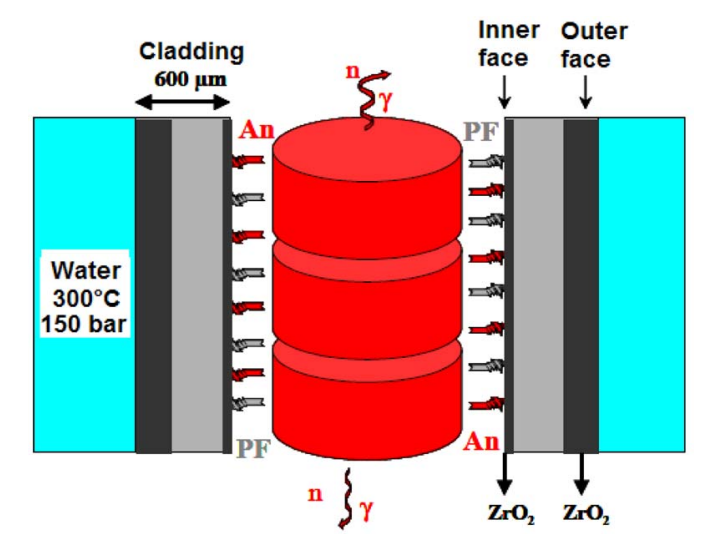

Figure 1. Schematical section of fuel rod in reactor. An and PF represent respectively the actinides and the fission products.

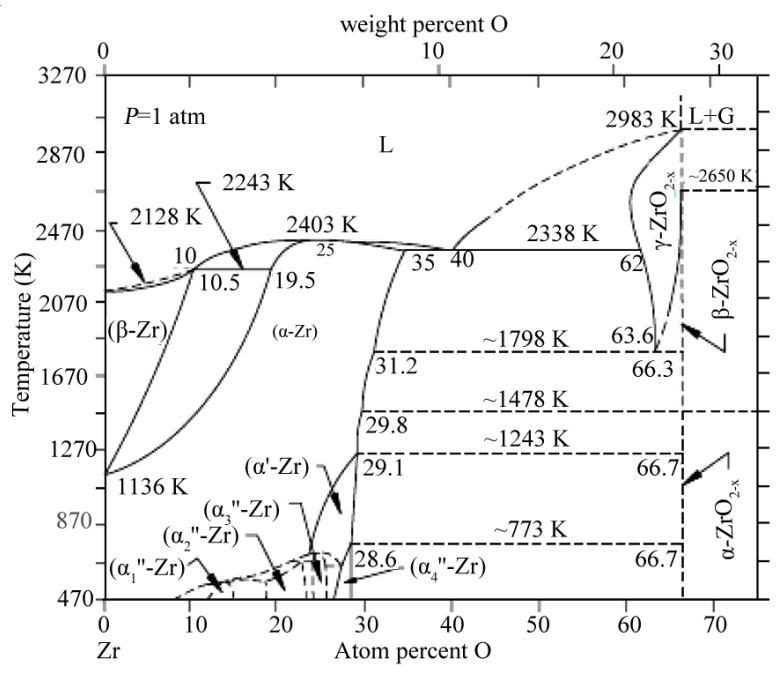

Figure 2. Equilibrium phase diagram for the $\mathrm{Zr}-\mathrm{O}$ system [2].

following global reaction $[6,7]$ :

$$
\mathrm{Zr}+(1-\mathrm{x} / 2) \mathrm{O}_{2} \rightarrow \mathrm{ZrO}_{2-\mathrm{x}}
$$

Only a part of the oxygen which arrives at the intern interface enters in this reaction; the other part is dissolved in subjacent metal [8].

Parise gave a relation between the values of oxygen diffusion coefficient in $\alpha$ zirconium between $300^{\circ} \mathrm{C}$ and $600^{\circ} \mathrm{C}[9]$ :

$$
\mathrm{D}=0594.10^{-14} \cdot \exp [-197237 / \mathrm{RT}]
$$

where $\mathrm{D}$ is in $\mathrm{m}^{2} \cdot \mathrm{s}^{-1}, \mathrm{R}=8.314 \mathrm{~J} \cdot \mathrm{mol}^{-1} \cdot \mathrm{K}^{-1}$ and $\mathrm{T}$ is in Kelvin.

This same type of relation was obtained by Debuigne for temperatures between $650^{\circ} \mathrm{C}$ and $850^{\circ} \mathrm{C}$ [8]:

$$
\mathrm{D}=444 \cdot 10^{-4} \cdot \exp [-214,016 / \mathrm{RT}] \mathrm{m}^{2} \cdot \mathrm{s}^{-1}
$$

Concerning the oxygen diffusion coefficients in zir- conia resulting from the oxidation of metal, Parise gives the following relation between $150^{\circ} \mathrm{C}$ and $500^{\circ} \mathrm{C}$ :

$$
\mathrm{D}=679.10^{-8} \cdot \exp [-131524 / \mathrm{RT}] \mathrm{m}^{2} \cdot \mathrm{s}^{-1}
$$

and between $400^{\circ} \mathrm{C}$ and $850^{\circ} \mathrm{C}$, Debuigne gives:

$$
\mathrm{D}=105.10^{-7} \cdot \exp [-122474 / \mathrm{RT}] \mathrm{m}^{2} \cdot \mathrm{s}^{-1}
$$

\section{Experimental Procedure}

We have studied the microstructure of Zry-4 as received ( $\alpha$ phase). To follow the oxidation kinetics, we used, in-situ $\mathrm{x}$-ray diffraction for different temperatures $\left(25^{\circ} \mathrm{C}\right.$, $350^{\circ} \mathrm{C}, 500^{\circ} \mathrm{C}, 830^{\circ} \mathrm{C}$ and $1000^{\circ} \mathrm{C}$ ), in-situ XRD for temperatures of $350^{\circ} \mathrm{C}$ and different times of ageing: $00 \mathrm{~min}$, $10 \mathrm{~min}, 20 \mathrm{~min}, 40 \mathrm{~min}$ and $60 \mathrm{~min}$.

During a postulated loss-of-coolant-accident (LOCA), the cladding tube is submitted in steam environment to a fast increase in the temperature (up to $800^{\circ} \mathrm{C}-1200^{\circ} \mathrm{C}$ ), which induces an accelerated oxidation phenomenon until quenching [1]. To simulate this case, we have done $\mathrm{X}$-ray diffraction with Zry-4 samples water quenched at $1050^{\circ} \mathrm{C}$ with different times at this temperature $(05 \mathrm{sec}$, $10 \mathrm{sec}, 30 \mathrm{sec}, 01 \mathrm{~min}, 02 \mathrm{~min}, 05 \mathrm{~min}, 10 \mathrm{~min}$ and 20 $\min )$.

The X-ray diffraction is realized on a diffractometer equipped with a vertical goniometric, provided with X-rays tube with copper anticathode $\left(\mathrm{K} \alpha_{\mathrm{Cu}}: 1,5406 \AA\right)$, the sample stages are spinner and "HTK-1200" furnace with a temperature that reaches $1200^{\circ} \mathrm{C}$.

The X-rays diffraction analysis parameters are the following:

Scan angle $(2 \theta)$ : [15 to 125$]$ and [25 to 65].

Step size $(2 \theta): 0,02$.

Counting time (s): 1 .

The studied material is the zirconium alloy of nuclear usage; the zircaloy-4. The X-Ray Fluorescence technique (XRF) defines the elementary chemical composition of this alloy (Table 1).

\section{Results and Discussion}

\subsection{X-Ray Diffraction}

The XRD for Zry-4 sample as received is shown in Figure 3.

Crystallographic structure of this material as received is the hexagonal close-packed structure ( $\mathrm{hcp}-\mathrm{Zr} \alpha$ ), this material has a polycrystalline metallographic structure with equiaxes grains and a microhardness $\operatorname{Hv}(0.5) \approx 180$ $\left(\mathrm{kg} / \mathrm{mm}^{2}\right)$.

\subsection{In Situ X-Ray Diffraction (Oxidation Kenitics)}

The Zry-4 sample has a diameter of $10 \mathrm{~mm}$ and a thick- 


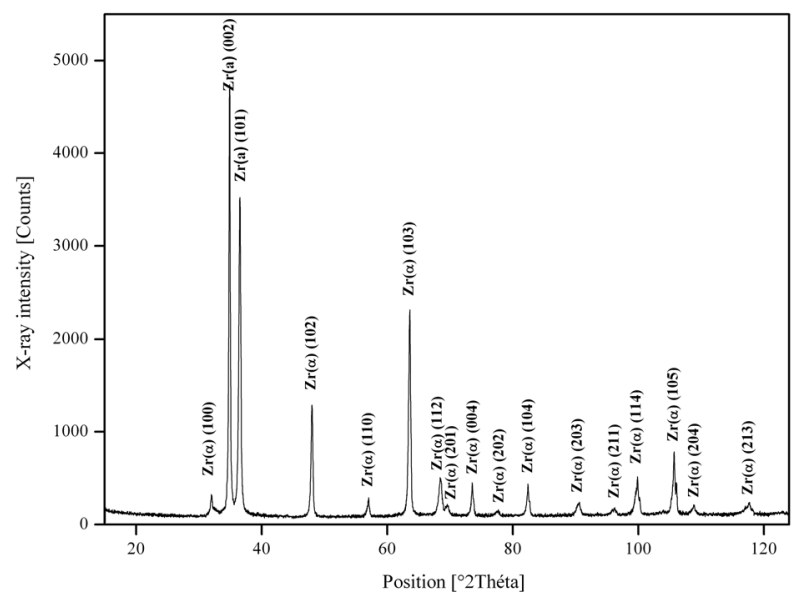

Figure 3. X-ray diffraction pattern of Zry-4 as received.

Table 1. Chemical composition of Zircaloy-4 (\%).

\begin{tabular}{cc}
\hline Element & Concentration \\
\hline $\mathrm{Zr}$ & 97.243 \\
$\mathrm{Sn}$ & 2.423 \\
$\mathrm{Fe}$ & 0.220 \\
$\mathrm{Cr}$ & 0.105 \\
$\mathrm{Hf}$ & traces \\
\hline
\end{tabular}

ness of $0.9 \mathrm{~mm}$, placed in "HTK-1200" furnace of the diffractometer. The different diffraction temperatures in air are: $25^{\circ} \mathrm{C}, 350^{\circ} \mathrm{C}, 500^{\circ} \mathrm{C}, 830^{\circ} \mathrm{C}$ and $1000^{\circ} \mathrm{C}$.

When the temperature of furnace is reached, the diffraction is immediately launched and the results are presented in the form of diffractograms.

The results of $i n$-situ XRD diffractograms prove that:

- For $25^{\circ} \mathrm{C}$, there is only $\mathrm{Zr}-\alpha$ phase, the principal peak of this phase is in $2 \theta=34.83^{\circ}$.

- The formation of the monoclinic and tetragonal phases start at $350^{\circ} \mathrm{C}$, principal peaks of monoclinic and tetragonal phases are respectively at $2 \theta=28.24^{\circ}$ and $30.28^{\circ}$

- From $350^{\circ} \mathrm{C}$ to $1000^{\circ} \mathrm{C}$, there is an important evolution in the two monoclinic and tetragonal zirconias, Figure 4.

- When the temperature is equal or up to $830^{\circ} \mathrm{C}$, there is a formation of $\mathrm{Zr}-\beta$ phase and disappearance of $\mathrm{Zr}-\alpha$ phase, the principal peak of $\mathrm{Zr}-\beta$ phase is at $2 \theta=$ $35.8^{\circ}$, Figure 4.

These results give the oxidation kenitic's of Zry-4, Figure 5.

For the room temperature $25^{\circ} \mathrm{C}$, There is only $\mathrm{Zr}-\alpha$ phase, the principal peak intensity is 10,787 counts, this intensity increases to 11,747 counts for $350^{\circ} \mathrm{C}$, and decreases rapidly to 8985 counts for $500^{\circ} \mathrm{C}$ until 1197 counts for $800^{\circ} \mathrm{C}$ and zero intensity for $1000^{\circ} \mathrm{C}$, which confirms the reduction in the volume fraction of this phase.

The reduction in the volume fraction of $\mathrm{Zr}-\alpha$ phase is directly related to the formation of the $\mathrm{ZrO}_{2}$ zirconia on the sample surface.

On the other hand, and for $25^{\circ} \mathrm{C}$, zero intensity for monoclinic and tetragonal $\mathrm{ZrO}_{2}$ zirconias. The $\mathrm{X}$-rays diffracted intensities are increased progressively from $350^{\circ} \mathrm{C}$ to $1000^{\circ} \mathrm{C}$.

For monoclinic zirconia: 388 counts for $350^{\circ} \mathrm{C}, 697$ counts for $500^{\circ} \mathrm{C}, 2957$ counts for $830^{\circ} \mathrm{C}$ and 2070 counts for $1000^{\circ} \mathrm{C}$.

For tetragonal zirconia: 371 counts for $350^{\circ} \mathrm{C}, 438$ counts for $500^{\circ} \mathrm{C}, 827$ counts for $830^{\circ} \mathrm{C}$ and 629 counts for $1000^{\circ} \mathrm{C}$.

Therefore, we have an increase in the volume fraction of zirconias with the increase in the temperature because of the oxygen diffusion.

\subsection{Ageing in HTK-1200 Furnace}

We have done in-situ XRD at $350^{\circ} \mathrm{C}$ and at different times of ageing: $00 \mathrm{~min}, 10 \mathrm{~min}, 20 \mathrm{~min}, 40 \mathrm{~min}$ and 60 $\min$ (Figure 6).

We put the sample during a fixed time of ageing in $350^{\circ} \mathrm{C}$ before starting the diffraction again. The holding time enables us to study the influence of the time on the formed phases.

During a typical Loss-Of-Coolant-Accident (LOCA) transient, the fuel cladding tubes are subject to high temperature oxidation that reaches $1000^{\circ} \mathrm{C}$ and finally quenched because of the reflooding of the core. The global oxygen content and its distribution affect strongly the proprieties of the cladding which microstructure can be described in terms of zirconia phase.

We have studied this case with $\mathrm{x}$-ray diffraction technique on Zry-4 samples water quenched at $1050^{\circ} \mathrm{C}$ with different ageing times $(05 \mathrm{sec}, 10 \mathrm{sec}, 30 \mathrm{sec}, 01 \mathrm{~min}, 02$ $\mathrm{min}, 05 \mathrm{~min}, 10 \mathrm{~min}$ and $20 \mathrm{~min}$ ) at this temperature, the results are given in Figure 7.

For The $1050^{\circ} \mathrm{C}$ water quenching after 05 seconds, there is no formation of oxide layer, but at 10 seconds to 20 minutes; there is a clearly evolution of monoclinic and tetragonal zirconias on one hand, and on the other hand, there is a disappearance of the $\mathrm{Zr}-\alpha$ phase (Figure 7).

\subsection{Microhardness}

The indentation method allows the hardness of a material to be measured. The Vickers hardness of water quenching Zry-4 with $500 \mathrm{~g}$ weight is augmented to 207 $\left(\mathrm{kg} / \mathrm{mm}^{2}\right)$ at 05 seconds of ageing time to $1120\left(\mathrm{~kg} / \mathrm{mm}^{2}\right)$ at 300 seconds of ageing time (Figure 8).

\section{Conclusions}

The oxidation of zircaloy- 4 changes completely the 


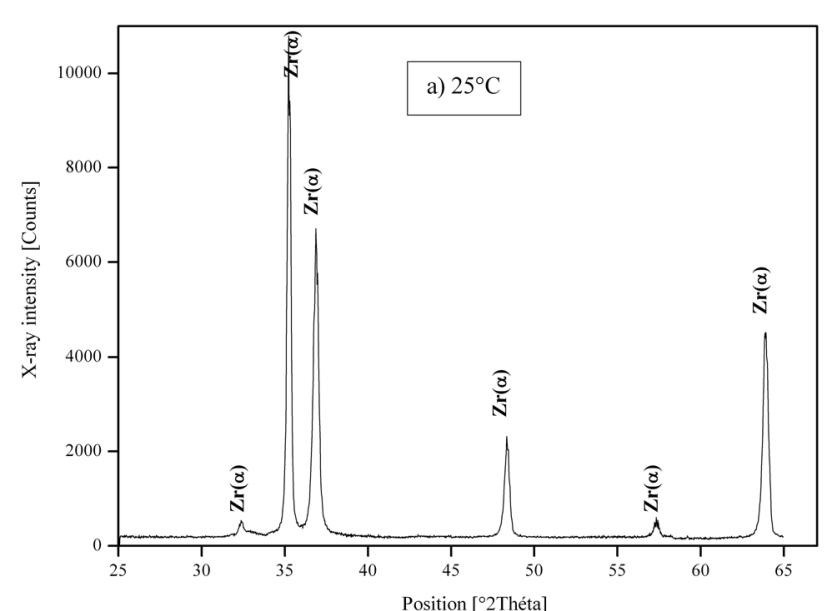

(a)

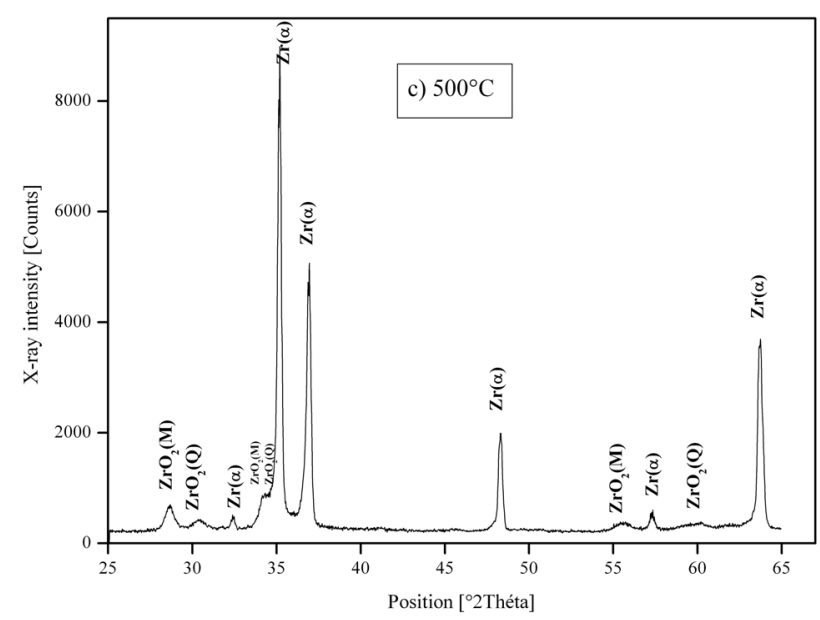

(c)

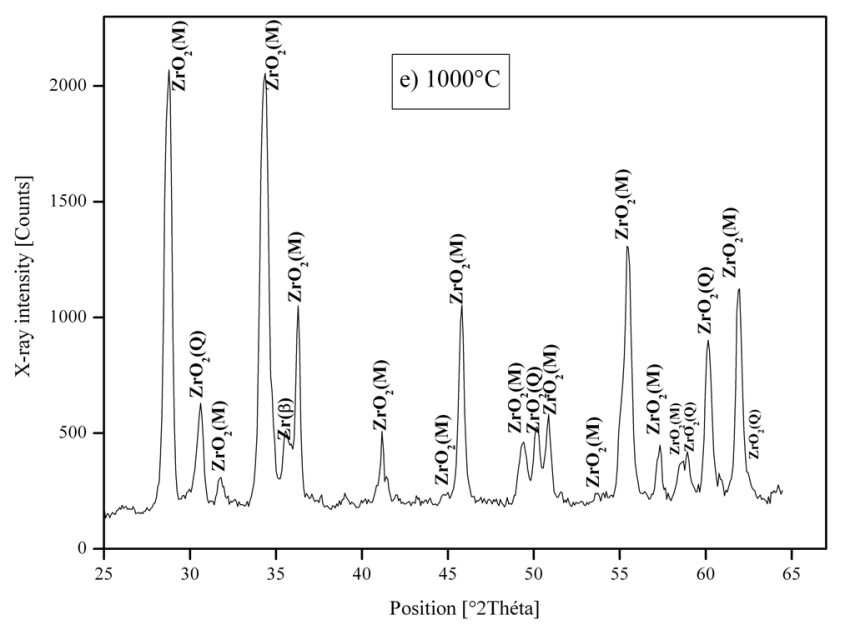

(e)

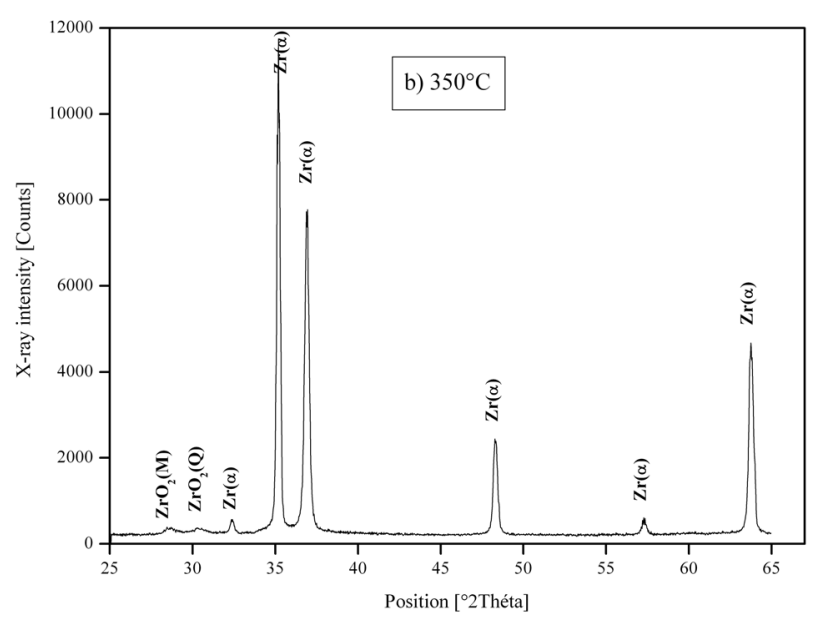

(b)

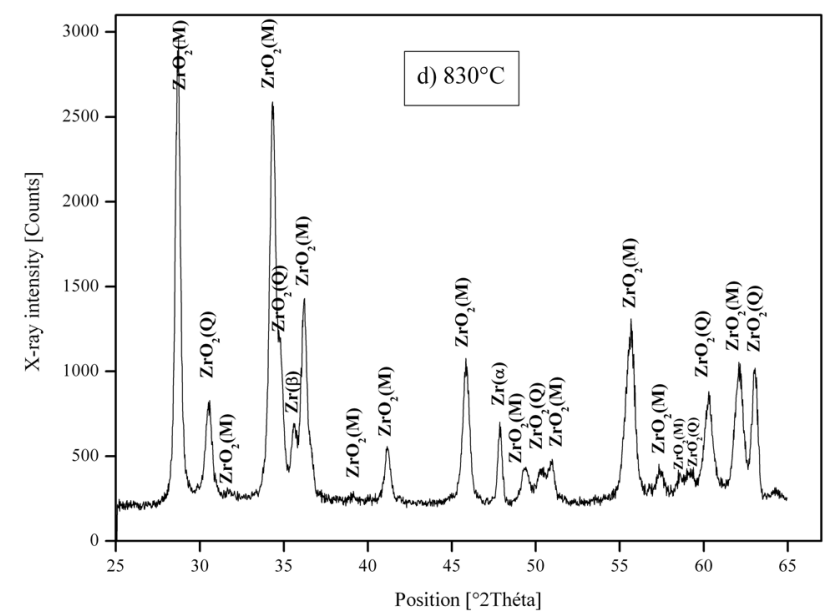

(d)

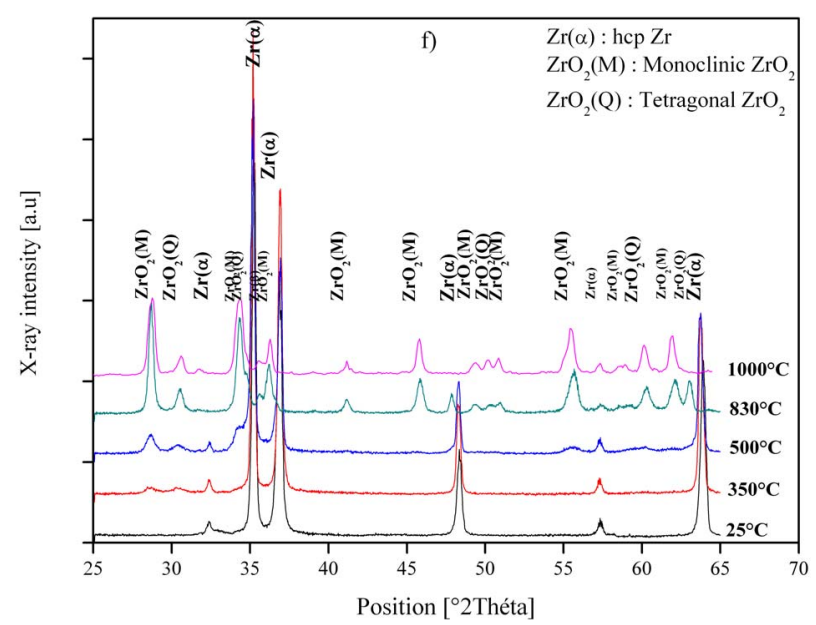

(f)

Figure 4. In-situ X-Ray diffraction patterns of Zry-4 for different temperatures: (a) $25^{\circ} \mathrm{C}$; (b) $350^{\circ} \mathrm{C}$; (c) $500^{\circ} \mathrm{C}$; (d) $830^{\circ} \mathrm{C}$; (e) $1000^{\circ} \mathrm{C}$; and (f) Combined graph.

properties of this material. In the presence of oxygen, and in temperature between $25^{\circ} \mathrm{C}$ and $350^{\circ} \mathrm{C}$, a great quantity of oxygen can dissolve in interstitial positions, the zir- caloy-4 maintains its properties. Between $350^{\circ} \mathrm{C}$ and $1050^{\circ} \mathrm{C}$, and with the use of $\mathrm{x}$-ray diffraction technique, we have an evolution of the two phases, monoclinic and 


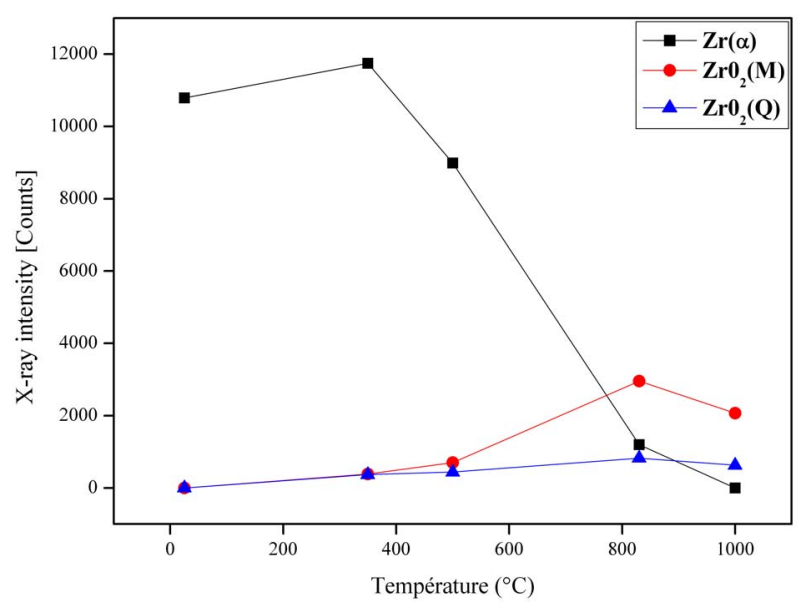

Figure 5. Evolution of the different phases in function of temperature.

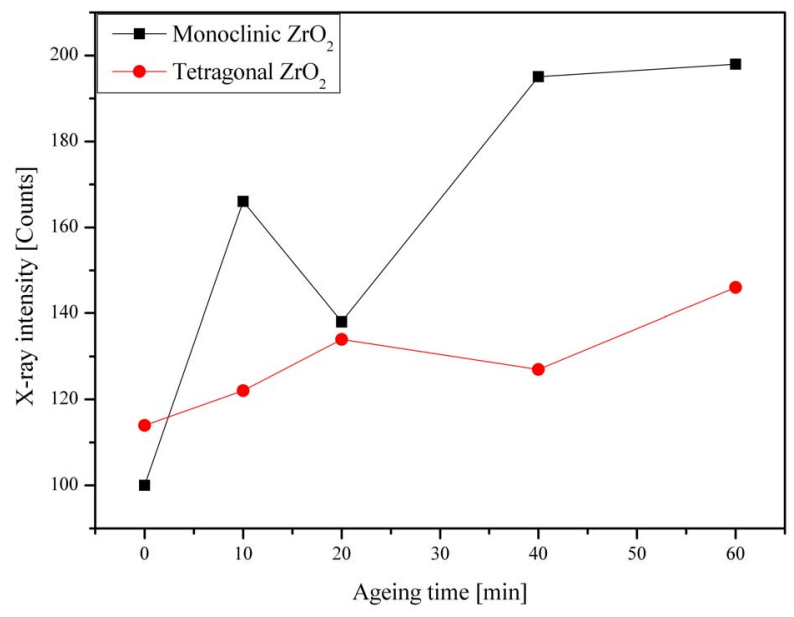

Figure 6. Evolution of the two formed zirconias (monoclinic and tetragonal) in function of ageing time at temperature of $350^{\circ} \mathrm{C}$ in the HTK furnace.

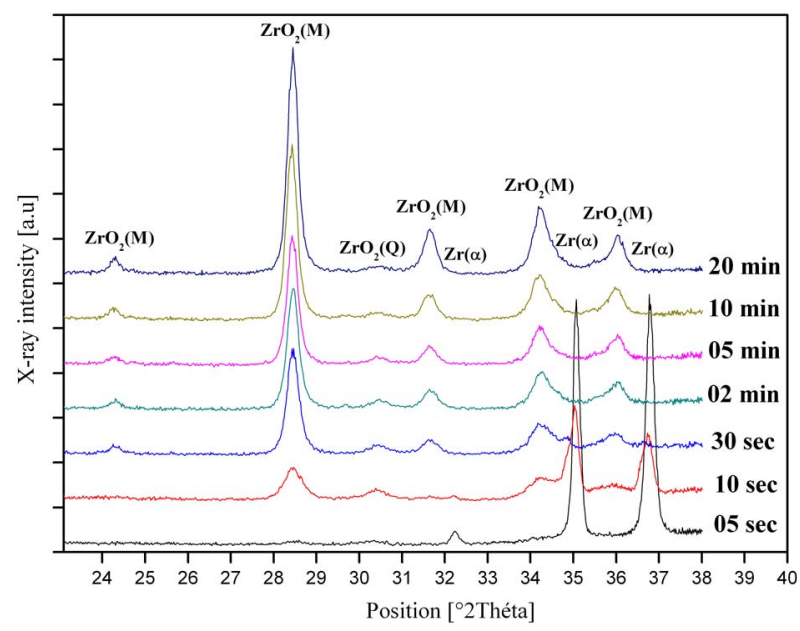

Figure 7. X-ray diffraction pattern of Zry-4 water quenched at $1050^{\circ} \mathrm{C}$ with different ageing times at this temperature.

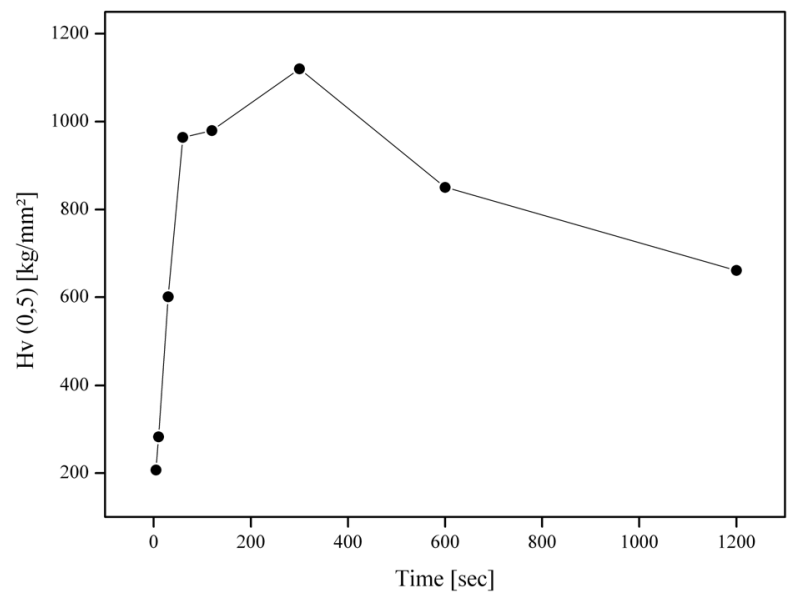

Figure 8. Microhardness (mHv (0.5)) for $1050^{\circ} \mathrm{C}$ quenched samples with different ageing times.

tetragonal zirconia where the zircaloys-4 loses its properties.

The formation of monoclinic and tetragonal zirconia leads to the increase in hardness and the reduction in thermal conductivity which leads to the degradation of zircaloy-4 mechanical and thermal properties. The microhardness of these oxides $\left(\mathrm{ZrO}_{2}\right)$ is very high, which increases the probability of cracking of this material, and consequently, the contamination of the primary circuit.

\section{REFERENCES}

[1] A. Stern, J.-C. Brachet, V. Maillot, D. Hamon, F. Barcelo, S. Poissonnet, A. Pineau, J.-P. Mardon and A. Lesbros, "Investigations of the Microstructure and Mechanical Properties of Prior-Structure as a Function of the Oxygen Content in Two Zirconium Alloys," Journal of ASTM International, Vol. 5, No. 4, 2008, Article ID: JAI101119.

[2] S. Banerjee and P. Mukhopadyay, "Phase Transformation: Examples from Titanium and Zirconium Alloys," Pergamon Press, Oxford, 2007, pp. 6-11, 42.

[3] D. Yacoub, "Experimental Study of Zirconium Alloys Oxidation at High Water Steam Pressure and Modelling of Mechanisms," Ph.D. Thesis, Superior National School of Mines, Saint-Etienne, 2007.

[4] N. Bererd, "Irradiation Effects on the Zirconium Oxidation and the Uranium Diffusion in the Zirconia," Ph.D. Thesis, Claude Bernard University-Lyon I, Chevarier Alain (Dir.), 2003.

[5] W. Qin, C. Nam, H. L. Li and J. A. Szpunar, "Tetragonal Phase Stability in $\mathrm{ZrO}_{2}$ Film Formed on Zirconium Alloys and Its Effects on Corrosion Resistance," Acta Materialia, Vol. 55, No. 5, 2007, pp. 1695-1701. doi:10.1016/j.actamat.2006.10.030

[6] N. Pétigny, "Comparison of Tow Zirconium Alloys Oxidation by in-Situ and ex-Situ X-Ray Diffraction: Texture, Phase," Ph.D. Thesis, Bourgogne University, Dijon, 1999.

[7] P. Putoud, "Alloys Oxidation of the Zircaloy-4 Type with Different Contents of tin at $400^{\circ} \mathrm{C}$ in the Steam. Analyzes 
of Phases in Presence and Their Evolution," Ph.D. Thesis, Compiegne Technology University, Compiègne, 1995.

[8] J. Debuigne, "Contribution in the Study of the Zirconium Oxidation and the Oxygen Diffusion in the Oxide and the Metal," Ph.D. Thesis, Paris University, Paris, 1966.
[9] M. Parise, "Mechanisms of Zirconium Alloys Corrosion: Study of the Oxidation initial Kinetics and the Mechanical Behaviour of the Metal-Oxide System," Ph.D. Thesis, Superior National School of Mines, Paris, 1996. 